\title{
Artes expresivas en la capacitación de docentes para la educación inclusiva: realidad portuguesa
}

Recibido: 7 de junio de 2018 / Revisado: 14 de junio de 2018

Aceptado: 15 de junio de 2018 / Publicado: 12 de julio de 2018

DUARTE SANTOS, GRAÇA

Departamento Psicologia/CIEP,

Universidad de Évora, Portugal

mgss@uevora.pt

CID, MARÍLIA

Departamento Pedagogia e Educação/CIEP,

Universidad de Évora, Portugal

mcid@uevora.pt

CARVALHO, ALEXANDRA

Universidad de Évora, Portugal

alexandrapcarvalho@gmail.com

DOI: 10.24310/IJNE1.1.2018.4952

\section{RESUMEN}

La Educación Inclusiva afirma la creación de igualdad de oportunidades para todos los niños. Para que esto suceda, es importante que los maestros, trabajando en aulas regulares, promuevan el potencial de los niños y que tiegan acceso a métodos y técnicas que les permitan desarrollar actividades educativas inclusivas. La creatividad, el aprendizaje cooperativo y el aprendizaje activo son métodos fundamentales para una Educación Inclusiva.

Este documento se centra en una investigación centrada en el análisis de programas de formación de docentes de pre-servicio para la Educación Inclusiva y cómo estos futuros profesionales podrían estar preparados para usar Técnicas Expresivas como métodos activos

\section{ABSTRACT}

Expressive Arts in Training of Teachers to Inclusive Education: Portuguese Reality

Inclusive Education claims the creation of equal opportunities for all children. To make this happen it is important that teachers, working in regular classrooms, promote children's potential having access to methods and techniques that enable them to develop inclusive educational activities. Creativity, cooperative and active learning are fundamental methods for an Inclusive Education.

This paper focus on a research centered on the analysis of pre-service teacher training programs for Inclusive Education and how these future professionals could 
privilegiados en la Educación Inclusiva. El estudio incluyó el universo de todas las instituciones de educación superior que ofrecen formación docente previa al servicio en Portugal desde la educación preescolar hasta el segundo ciclo de educación básica. Utilizando un método descriptivo de investigación, todos los datos fueron recolectados, analizados y categorizados en componentes dentro de la Educación Inclusiva y las Técnicas Expresivas. Los resultados muestran que las instituciones de educación superior tienen un gran porcentaje de componentes de capacitación en Educación Inclusiva y Técnicas Expresivas, más altas en instituciones públicas que en instituciones privadas. La mayoría de ellos tiene un componente teórico y práctico. Sin embargo, los resultados indican que ambos componentes no están cubiertos por un solo curso, es decir, Técnicas Expresivas en Educación Inclusiva.

El estudio llama la atención sobre un área fundamental: una Capacitación Inicial de Maestros consistente que vincula la educación en Técnicas Expresivas, Educación para Necesidades Especiales y Educación Inclusiva. Aunque no es exhaustivo, este estudio puede ser una contribución para promover la reflexión y el desarrollo de programas efectivos de capacitación de docentes antes del servicio, dando un aporte con estas áreas para construir modelos positivos de Educación Inclusiva.

PALABRAS CLAVE: Educación Inclusiva, Técnicas Expresivas, Capacitación de docentes. be prepared to use Expressive Techniques as active methods privileged in Inclusive Education. The study involved the universe of all higher education institutions that provide pre-service teacher training in Portugal from pre-school education to 2 nd cycle of basic education. Using a descriptive method research, all data were collected, analyzed and categorized in components within the Inclusive Education and Expressive Techniques. Results show that High Education Institutions have a large percentage of components training in Inclusive Education and Expressive Techniques - higher in public than in private institutions. Most of them have a theoretical and practical component. However, results indicate that both components are not covered by a single course, i.e., Expressive Techniques in Inclusive Education.

The study draws attention to a fundamental area: a consistent Initial Teachers Training that links education on Expressive Techniques, Special Needs Education and Inclusive Education. Although not exhaustive, this study can be a contribution to furthering the reflection and development of effective pre-service teacher training programs, giving an input with these areas to build positive models of Inclusive Education.

KEYWORDS: Inclusive Education, Expressive Techniques, Teachers training.

\section{Introduction}

\subsection{Inclusive Education}

The Declaration of Salamanca (1994) introduced a paradigm shift in Education, allowing not only an increase of literature and investigation on Inclusive Education, but essentially a deep reformulation, 
in many countries, of their educational praxis. This reformulation had as a main goal to create an environment and culture where all students can enjoy learning, reflect, improve and grow in confidence, in a perspective of inclusive teaching and Education.

Inclusive Education consists in an educational movement designed to create equal opportunities for all children. To make this happen it is important that teachers working in regular classrooms promote children's potential and have access to methods and techniques that enable them to develop inclusive educational activities. This involves understanding inclusion not as merely social belonging but working to raise students' academic and other developmental levels (Lebeer et al. 2013).

According to a report published by the European Agency for Development in Special Needs Education (2003) practice of inclusive education should be based, essentially, on a quality education that promotes a truly inclusive educational differentiation, achieved among other aspects using cooperative work, action in partnership, promotion of working groups and work with peers.

The development of all these intervention strategies more focused on relational context than in the individual permit the emergence of a sense of belonging, facilitating collaboration and friendship (Soodak, 2003; Westwood, 2004).). Hughes and Kwok (2007) refer that an interactive relationship enhances student motivation which in turn renders them more interested in and engaged in the learning process. In fact, if strong academic instructional practices are necessary also social and emotional factors are very important in this area, as evidenced by Reicher's studies (2010) about the links between social and emotional learning and Inclusive Education. For Cohen (2006) the goals of Education need to be reframed to prioritize not only academic learning, but also social, emotional, and ethical competencies by creating a safe and caring school climate. So, to achieve these goals, classroom climate is fundamental (Suleymanov, 2015).

Classroom climate, as a strong mediator of values, beliefs and standards that involve all learning, is one of the determining factors on learning and students' development and on development of all inclusive practices (at the level of teaching strategies, attitudes and organizational factors). Studies on the interaction between psychosocial aspects, strategies and teaching attitudes indicate the importance of classroom climate on pupils learning, showing that they achieve much better in classrooms with an academic environment where they feel happy (Westling Allodi, 2002; Bond \& Castagnera, 2006). In this perspective, teachers' behaviors have a strong role modeling relationship within the group. But also important are strategies that enable the development of an environment of openness, recognition and happiness. Costa, Leitão, Morgado and Pinto (2006) refer that teachers must find different and alternative forms of communication. As such, for all those topics Expressive Arts in schools can give an important contribution. 


\subsection{Expressive Arts and Inclusive Education}

The deep connection between Expressive Arts and Education involves aspects that, beyond those associated with aesthetic aspect, impacts the full development of the child and the youngster, because it touches their cognitive, socio-emotional and neuro-motor development (Santos, 1999). The movement of Education through Art is founded on these assumptions (Read, 1982; Santos, 2008). The International Society for Education through Art (2015) claims that Education through Art is a natural means of learning, fostering values and disciplines essential for full intellectual, emotional and social development of human beings in a community having the power to bring about internal self-reflection, empathic appreciation of human diversity and respect for differing worldviews among groups of people. Through the arts, students may harmonize their own deeply held beliefs with the worldviews of others, developing a deep sense of happiness, recognizing and being recognized in difference.

Expressive Arts differ from Art Education valuing the focus on Expression rather on learning artistic skills. Expressive Arts integrates various mediators as dance/movement, painting, drawing, modeling, drama, poetry, music and emerge as privileged practices and strategies of intervention, valuing ludic character, working in a multimodal relational way (in a cooperative work, in pairs or groups), contributing to greater adherence and involvement of populations they are addressed (Santos, 2008; Deans, 2009). This impact of Arts promoting child and youngster's development also contributes to fundament their intervention both on an educational and a therapeutic perspective. We highlight also the therapeutic power of the expressive-creative act (Santos, 1999) echoing in approaches as music therapy, drama therapy, dance therapy, art therapy and others. As they are essentially non-verbal approaches, expressive mediators are privileged means of communication with children and youngsters with special needs education (Santos \& Simões, 2009) with importance in development of personal, social and learning skills. Furthermore, through imagination and creative ability, children can express themselves with greater ease and satisfaction in a group, and this becomes an important issue of Inclusive Education. In that way, many countries are increasing the interventions through Expressive Arts as promoters of development in several areas and skills in the field of Special Needs Education or Inclusive Education (Regev \& Guttmann, 2005; Peter,2009; Karkou,2010; McFerrana, Thompsona \& Bolgerb, 2015; Santos, 2009; Carvalho, 2013; Mayesky, 2009; Rees, 2005; Gilberstson \& Aldridge, 2008).

Ho et al. (2012) refer that an additional feature of Expressive Arts in education is their therapeutic origins as non-judgmental and supportive which potentially transforms the classroom into a learning community where everyone has a contribution. Thomas and Mulvey (2008) reported that when the arts are used in this manner, learning was enhanced for both students and teachers, as this process involves the exchange of ideas and opinions among students and also between students and teachers. 


\subsection{Expressive Arts and Teacher Education}

Currently UNESCO and European Agency for Development in Special Needs Education are also working together with the project Inclusive Education in Action - IEA (2015). This project is developed on five areas, one of them is Teachers and Teacher Education where are presented 46 examples of studies or projects. Some of them reflect on Inclusive Education through the Arts, as relevant to various areas of the UNESCO Policy Guidelines as the following: F3: Strengthen early childhood care and education provisions, linking them to inclusive approaches; J1: Provide support when needed and make curricula open and flexible, allowing for different learning styles and content that makes the curriculum relevant to learners and society; J4: Ensure that curricula do not focus only on academic skills; J5: Encourage new methods and new ways of learning; K3: Promote the use of new and alternative methods for teaching; K5: Encourage teachers to organize their work in teams and to apply problem oriented teaching methods as well as paying respect to diversity and different learning styles among their pupils.

These data illustrate the importance allocated to the Expressive Arts in teacher education and practices for inclusion.

Teacher education is a key resource for the construction and affirmation of an inclusive school, promoting the development of attitudes, knowledge and personal skills and teaching to serve interests and aims of Inclusive Education. In order to achieve the success of every student, Schaffner and Buswell (1999) mention that, among other factors, it is crucial that teachers acquire scientific and educational skills even beyond those transmitted in their initial training courses. And beyond this, it is also necessary that teachers develop and update relational and emotional skills that enable an authentic positive climate in their practices of Inclusive Education. (Santos, Ljusberg \& Candeias, 2009).

The role of higher education institutions in training for an Inclusive Education is vital. To Costa, Leitão, Morgado and Pinto (2006) the initial and specialized teacher training must contemplate knowledge and skills inherent to the development of models and educational practices that promote inclusion and quality; the practical component of initial teacher training courses should be increased so that the future teachers are exposed to positive models of Inclusive Education.

Attending to the importance given to creativity and active learning in inclusive curriculums as well as the practical component in teacher training, we consider that active methods and Expressive Techniques - contributing to this positive model of Inclusive Education - must be learning and lived in an experiential practice that promotes teachers' development of personal and interpersonal competences, crucial for professional practice (Santos \& Vaz-Velho,2011; Lima-Rodrigues, 2014). 


\subsection{Educational system and teacher training in Portugal}

The Portuguese educational system comprises pre-school (for those under age 6), basic, secondary and higher education. Compulsory Education lasts for 12 years and is divided into Basic and Secondary School Education. Basic Education is divided into three cycles: first cycle (1st to 4th grade); second cycle (5th and 6th grade); third cycle (7th to 9th grade). The Secondary Education includes 10th, 11th and 12 th grade.

Teacher training in Portugal is carried out in higher education institutions: universities (departments or faculties related to Social Sciences) and Polytechnics (Higher Education Schools). Pre-service teacher training comprises a first cycle of three years (Graduation) which includes a broad training in Basic Education for pre-school to fourth grade teachers and subject training (Biology and Geology, Physics and Chemistry, Mathematics, etc.) for training specific subject teachers. In sequence, the training is completed with a second cycle of one to two years (master's degree) where pedagogical and subject matters are taught and professional qualifications acquired.

As the program of study is not currently integrated, students can do their training (first and second cycles) in different institutions of higher education.

In Portugal, the Educational System Law determined in 1986 that Special Education is to be organized "according to diversified models of integration in regular schools" (Article 18, paragraph 1), but the right to education and school integration only came to have full implementation with the assumption of compulsory education for children and youngsters with disabilities through Law No. 35/90, January 25.

The concept of inclusive schools is clarified in Law No. 21/2008, May 12, which defines the specialized support to offer and the measures to improve the education of students with special needs. This law states that Special Education aims to educational and social inclusion, facilitate access and educational success, autonomy, emotional stability, and the promotion of equal opportunities, preparation for further study or for proper preparation for post-school or professional life.

This law follows the publication of article 24 of the United Nations Convention which claims that children with special educational needs have the right to be educated in regular schools' settings together with non-disabled peers and countries should adopt measures in accordance. Portugal adapted its law to make education more inclusive and turn school accessible to all children whatever their background or differences. In fact, this is a big challenge to all countries involved as it means a system that includes all children no matter their conditions but also a system that prevents dropouts caused by any disabilities (Gogacz, 2013). 
Despite this assignment, present legislation on professional qualification for teaching in Pre-school Education and Basic and Secondary Education (Law 43/2007, February 22) does not mention the obligation of including special education subjects in pre-service teachers training programs, which results in a great diversity of responses from training institutions.

Regarding the introduction of Expressive Arts in teacher training, Portugal was a pioneer country in Europe, with a teachers training program in Education through Art. This Graduate program was held between 1971 and 1982 and trained hundreds of teachers (Brederode, 1994; Valente, Lourenço \& Charréu,1998). Many of them opted to work with children and youngster with special needs education in schools and in community projects (Valente, 1984). In 1982, the High School of Education through Art was closed but many seeds were planted for the future, promoting curricular changes in both Basic Education and Teacher Education (Santos, 1989; Valente, Peixoto \& Craveiro-Lopes, 2003). So, we ask: what is really happening now at the Expressive Arts level as a component of teacher education for Inclusive Education?

\section{Method}

This study is centered on the analysis of teachers training for Inclusive Education and their preparation on Expressive (Arts) Techniques as active methods privileged in Inclusive Education. Previous studies (Oliveira, 2009) have concluded that only three of the thirteen public higher education schools in Portugal contemplate a semi-annual course related to Inclusive Education in graduation, the Basic Education program. Our concern was to understand if those important areas are reflected in different aspects of teacher training and, if so, how they are organized.

To that extent, the study developed fits in the scope of Descriptive Research and can be classified as Documentary Research as depended on existing documents, which can be an important and rich source of data for social research (Punch, 1998).

The main goal of the research was to identify if the concepts of Inclusive Education and Expressive Techniques were included on the curricular plans of pre-service teacher training programs in higher education schools in Portugal. As specific goals we were interested in confronting data from Universities and Polytechnic Institutes, from public and private education. The focus was to describe the components in training as they are contemplated or not; if they are mandatory or optional; if they are theoretical, practical or both; as well as the analysis of their goals and contents.

To achieve these objectives, it was first listed the undergraduate and master programs of public and private higher education with relation to pre-service teacher training, in the academic year 2010/2011. 
Subsequently there were identified all curricular plans in order to list what courses had training components in Inclusive Education and Expressive Techniques. After that we proceeded to the analysis of their objectives and program content.

This research study then included the curricula of all initial teacher training programs (Graduation and Master's degrees) in Portugal conferring qualifications for teaching pre-school and for first and second cycles of Basic Education. All higher education schools in Portugal that offer pre-service training to teachers were identified (mainland and islands). The curricula were obtained by consulting their websites and/or by consulting the "Diário da República" law, a journal where curricula are published after government approval; the goals and contents of the courses that contemplated the areas relevant for this study were analyzed.

A total of 74 institutions/faculties of higher education were identified in a total of 383 programs of teachers training. We had access to 350 program syllabus and there were identified 599 different courses, selected on the following key-words: education; inclusive education; pedagogy; special needs; arts; expressions.

The data collected were inserted and treated with PASW 18 program, according to the analytical dimensions shown in Table1, validated by other two researchers.

\section{Analytical Dimensions}

Institution and Program

Higher Education Institution

Program Title

Geographic Zone

Type of Higher Education Institution (Public/ Private)

Polytechnic Education / University education

Training Component (Expressive Technics /

Inclusive Education)

Graduation/ Master
Course
Course Title

Mandatory / Optional

Year and Semester

Learning Methodology

Objectives

Number of Credits

Contents
Theoretical / Theoretical-Practical / Practical

Table 1. Dimensions of Data Analysis. 


\section{Results and discussion}

The results obtained were organized in accordance with the analytical dimensions already presented and the main data are summarized in the following tables.

As table 2 shows, there are 51 institutions of higher education (69\%) that offer 155 courses with training components in Inclusive Education (IE) and 38 institutions (51\%) offer 321 courses with training components in Expressive Techniques (ET). We also verified that in 123 of the 599 analyzed cases there were no training components in IE or ET.

\section{Training Components}

\begin{tabular}{|c|c|c|c|}
\hline & Inclusive Education & Expressive Techniques & Without these Components \\
\hline Number of Institutions & $\begin{array}{c}51 \\
(69 \%)\end{array}$ & $\begin{array}{c}38 \\
(51 \%)\end{array}$ & $\begin{array}{c}53 \\
(72 \%)\end{array}$ \\
\hline Number of Courses & 155 & 321 & 123 \\
\hline
\end{tabular}

Table 2. Number of Courses with Training Components in Inclusive Education and Expressive Techniques in Higher Education.

The institution that presented the highest number of courses with Inclusive Education (IE) explicitly mentioned in the several programs of pre-service teacher training reaches a total of 10. With Expressive Techniques (ET), the highest value recorded in an institution was 18 courses.

Comparing the results from Public Universities and Polytechnic Institutes we verify that Polytechnic Institutes have a higher number in training components in IE (61 in 97), corresponding to 63\%, as well as in ET (128 in 188), corresponding to $68 \%$, as can be seen in table 3 . 


\section{Number of Courses and Training Components}

Type of Institution

$$
\text { Inclusive Education Expressive Techniques Without these Components }
$$

\begin{tabular}{|c|c|c|c|}
\hline University & $\begin{array}{c}36 \\
(37 \%)\end{array}$ & $\begin{array}{c}60 \\
(32 \%)\end{array}$ & $\begin{array}{c}40 \\
(43 \%)\end{array}$ \\
\hline Polytechnic & $\begin{array}{c}61 \\
(63 \%)\end{array}$ & $\begin{array}{c}128 \\
(68 \%)\end{array}$ & $\begin{array}{c}52 \\
(57 \%)\end{array}$ \\
\hline Total & 97 & 188 & 92 \\
\hline
\end{tabular}

Table 3. Number of Courses and Training Components in Public Universities and Polytechnics.

Comparing the results between Private and Public education (Table 4), we found that the offer of IE and ET training components is higher in public institutions of higher education than in the private ones (63\% against $37 \%$ for IE; $59 \%$ against $41 \%$ for ET) (Carvalho, 2013, p. 68).

\begin{tabular}{|c|c|c|c|}
\hline \multirow{2}{*}{ Type of Institution } & \multicolumn{3}{|c|}{ Number of Courses and Training Components } \\
\hline & Inclusive Education & Expressive Techniques & Without these Components \\
\hline Public & $\begin{array}{c}97 \\
(63 \%)\end{array}$ & $\begin{array}{c}188 \\
(59 \%)\end{array}$ & $\begin{array}{c}92 \\
(75 \%)\end{array}$ \\
\hline Private & $\begin{array}{c}58 \\
(37 \%)\end{array}$ & $\begin{array}{c}133 \\
(41 \%)\end{array}$ & $\begin{array}{c}31 \\
(25 \%)\end{array}$ \\
\hline Total & 155 & 321 & 123 \\
\hline
\end{tabular}

Table 4. Number of Courses and Training Components in Private and Public Education.

As for these courses being mandatory or optional, we concluded that the vast majority (426 in 476) are mandatory in the programs they are part of (Table 5). 


\begin{tabular}{ccc}
\hline & \multicolumn{2}{c}{ Number of Courses and Training Components } \\
\cline { 2 - 3 } Mandatory/ Optional Course & Inclusive Education & Expressive Techniques \\
\hline Mandatory & 126 & 300 \\
& $(81 \%)$ & $(93 \%)$ \\
Optional & 29 & 21 \\
& $(19 \%)$ & $(7 \%)$ \\
\hline Total & 155 & 321 \\
\hline
\end{tabular}

Table 5. Number of Mandatory versus Optional Courses and Training Components.

In $58 \%$ of the cases the information about the nature of these courses was not specified. About the courses we could get information, most of them are theoretical-practical as shown on Table 6. With topics on IE none of them are exclusively practical, 62 are theoretical-practical (40\% including all cases and $93 \%$ if excluding the non-specified cases). In 321 cases where there is training component in ET, 126 are theoretical-practical (39\% including all cases and $72 \%$ if we exclude the non-specified situations).

\begin{tabular}{|c|c|c|c|}
\hline \multirow{2}{*}{ Type of Course } & \multicolumn{2}{|c|}{ Number of Courses and Training Components } & \multirow[b]{2}{*}{ Total } \\
\hline & Inclusive Education & Expressive Techniques & \\
\hline Theoretical & $\begin{array}{c}5 \\
(3 \%)\end{array}$ & $\begin{array}{c}2 \\
(1 \%)\end{array}$ & $\begin{array}{c}7 \\
(2 \%)\end{array}$ \\
\hline Theoretical-Practical & $\begin{array}{c}62 \\
(40 \%)\end{array}$ & $\begin{array}{c}126 \\
(39 \%)\end{array}$ & $\begin{array}{c}188 \\
(39 \%)\end{array}$ \\
\hline Practical & $\begin{array}{c}0 \\
(0 \%)\end{array}$ & $\begin{array}{c}6 \\
(2 \%)\end{array}$ & $\begin{array}{c}6 \\
(1 \%)\end{array}$ \\
\hline Not Specified & $\begin{array}{c}88 \\
(57 \%)\end{array}$ & $\begin{array}{c}187 \\
(58 \%)\end{array}$ & $\begin{array}{c}275 \\
(58 \%)\end{array}$ \\
\hline Total & 155 & 321 & 476 \\
\hline
\end{tabular}

Table 6. Number of Theoretical, Theoretical-Practical and Practical Disciplines and Training Components. 
Analyzing the-goals and contents of the courses and those with training components in Inclusive Education (IE), we verify that, generally, they appear in two situations: in programs linked to general education (Basic Education, for instance) and Educational Sciences, or in programs related with Sport and Physical Education. In the first case, programs linked to general education and educational sciences, the-courses are called Special Education, Special Needs Education or similar to these.

Regarding goals and contents of these courses they focus generally the following items: the conceptual knowledge of Inclusive Education and special educational needs; the acquisition of competences in identifying different kinds of special educational needs; intervention strategies for these children; and acquisition of competences for an educational intervention orientated towards inclusion. A specific courses called Psycho-pedagogical Aspects of Inclusion stands out as referring directly to IE. The goals and contents of this one include those mentioned above and also some related to development of personal and ethical competences related to the defense of Human Rights and discussion of results from investigations in IE. There are also two situations where Portuguese Gestural Language is taught although it is an optional course in both cases. There are also courses with training components in IE in programs related to Sports and Physical Education. In these cases, those units are called Adapted Physical Education and Special Populations or Sports for Special Populations. These units contemplate working with two main kinds of people: seniors and children with special needs. Goals and contents for these units are generally the same in all schools, they aim at developing skills in evaluating, defining and adjusting physical education programs to these populations (according with their abilities and functional profile, enhancing or restoring possibilities for adaptation and development) and also analyzing sports and their therapeutic, recreational and social integration value in the process of rehabilitation.

Looking at goals and contents of the courses with training components in Expressive Techniques (ET), their names are explicit: Expressions or Pedagogy of, for instance, Musical Expression, Arts, Movement and Physical-motor Expression or Drama. As for their goals, they include acquiring skills in these areas and developing them with children from pre-school to second cycle of Basic Education. In some of these cases, concepts like Education through Arts and Artistic Education are addressed and in others the goals include knowledge of legislation for these areas.

Our results point to the fact that both components are never covered by a single course, where the use of Expressive Techniques as arts mediators are taught and reflected on the work with children with special educational needs in inclusive educational settings. There are however two exceptions: Music and Special Educational Needs, in which is mentioned the specific goals "Improving knowledge on significant and slight special needs", "Applying music as an intervention in cognitive, affective and behavioral dimensions"; and the courses Initiation to Music therapy that aims at bringing together music and its therapeutic use for children with special needs education. 


\section{Conclusions}

As pre-service teachers training is fundamental for the development of their future praxis, it is important to know not only the basic skills necessary for new teachers, but also realize the best way to acquire them. This aspect becomes particularly important when referred to teacher training for Inclusive Education, where professional quality of teachers and other educators are the basis for their promotion.

In the present study we found that $69 \%$ of Portuguese higher education institutions responsible for teacher training have courses with training components in Inclusive Education based mainly on the basic concepts of inclusion and special educational needs. This result meets only in part the obligation of the existence of such training since 1987 in our country (Rodrigues, 2006), revealing that there are yet many work to do, namely at the universities. It was also found that the vast majority of courses are mandatory. Regarding the practical component, we found that $93 \%$ of courses with training in Inclusive Education Component, whose programs were provided to us, had a theoretical and practical character. We question however what kind of connection is made between theory and practice.

Another dimension of this study was to verify the existence and to characterize the subject areas with training components in Expressive Techniques. We found that $51 \%$ of the higher education institutions include them in their curricula, with 39\% having a theoretical and practical character. We noticed, likewise, that the objectives and content of these courses contemplate only the scientific-technical view and the general didactic aspects of the Expressions. These didactic dimensions seem to be developed on a perspective of acquisition of knowledge and not on an experiential perspective in terms of the exploration of teachers' expressivity dimensions. The experiential dimension could help them towards an embedded knowledge (Santos \& Lima-Rodrigues, 2016) and consequently being exposed to positive models of Inclusive Education (Costa et al., 2006).

We also verified that there was no specification about the practice of Expressive Techniques as mediators in the work with students with special needs education.

Generally, by analyzing both components, it was possible to verify that the presence of these topics is more evident in polytechnic education (respectively 63\% for Inclusive Education and 68\% for Expressive Techniques) when compared to universities.

This may be related with the basic characteristics of Polytechnic Education, in its origin with contents more linked to the training of specific professions. We also noticed that the offer of training components of Inclusive Education and Expressive Techniques is more available in public higher education establishments. 
One of our concerns about the results is related to the absence of these training components in some programs. Being the Musical Expression, Drama, Visual arts and Physical expression present in the Basic Education curriculum, one would still expect a higher percentage of courses with this training component. We questioned the actual importance of those areas that seem not to be yet (or to be less and less) duly recognized in our schools, and we recall one of the conclusions of the World Conference on Arts Education (2006, Lisbon) which states that "programs of general training of teachers do not make a proper promotion of the role of arts in teaching and learning."

The present study aims at modestly contributing to the reflection and possible development / modification of program syllabus in pre-service teacher training in Portugal. In what concerns the contents of these two areas, there is still a long way to go on the implementation of Inclusive Education and Expressive Techniques as tools for the work with students with special needs education.

The practice of these guidelines to Inclusive Education requires also a deep involvement of the teachers (even after their graduation), reflecting not only on their professional skills but also reflecting on their own personal and social skills. This means that training teachers for an inclusive school probably cannot restrict us to a traditional academic education but must provide for a new training model that involves also new processes of scientific research.

\section{References}

Bond, R., \& Castagnera, E. (2006). Peer supports and inclusive education: An underutilized resource. Theory into Practice, 45(3), 224-229.

Brederode-Santos, M. E. (1994). Avaliação da Escola Superior de Educação pela Arte. Lisboa: IIE/ Ministério da Educação.

Carvalho, A. (2013). Formação de professores para a educação inclusiva: O lugar dos métodos activos e técnicas expressivas (Master dissertation). University of Évora.

Cohen, J. (2006). Social, emotional, ethical, and academic education: Creating a climate for learning, participation in democracy, and well-being. Harvard Educational Review, 75, 20137.

Costa, A.M.B., Leitão, F.R., Morgado, J. \& Pinto, J.V. (2006). Promoção da educação inclusiva em Portugal - Fundamentos e sugestões. Conferência Nacional de Educação Especial, Lisboa. 
Deans, J. (2009). Friends on the farm - reciprocal relationship building through the arts. The University of Melbourne refereed e-Journal, 1(4).

European Agency for Development in Special Needs Education (2003). Inclusive education and classroom practice: Summary Report. Brussels: Author.

European Agency for Development in Special Needs Education (2010). Teacher education for inclusion International Literature review. Brussels: Author

Gilberstson, S. \& Aldridge, D. (2008). Music therapy and traumatic brain injury. Philadelphia, U.S.A.: Jessica Kingsley.

Gogacz, A. (2013). The right to inclusive education and equality in opportunities. In J. Lebeer, L. Grácio, H. Sart, B. Schraepen, N. Babur, R.V. Eynde, L. Stoffles \& A. Cogacz (Eds). A preventive approach in inclusive education. Differentiating classroom practice for primary school teachers. In service training guide. Istanbul: Bogazici University Press.

Ho, R., Fan, F., Lai, A., Lo, P., Potash, J., Kalmanowitz, D., Nan, J., Pon, A., Shi, Z., \& Chan, C. (2012). An expressive arts-based and strength-focused experiential training program for enhancing the efficacy of teachers affected by earthquake in China. Creative Education, 3(1), 67-74. doi.org/10.4236/ce.2012.31011

Hughes, J., \& Kwok, O. M. (2007). Influence of student-teacher and parent-teacher relationships on lower achieving readers' engagement and achievement in the primary grades. Journal of Educational Psychology, 99, 39-51. doi:10.1037/0022-0663.99.1.39

International Society for Education through Art (2015). About. Retrieved from http://www.insea. org/insea/about

Inclusive Education in Action - IEA (2015). Retrieved from http://www.inclusive-education-inaction.org/iea/

Lebeer, J., Grácio, L., Sart, H., Schraepen, B., Babur, N., Eynde, R.V., Stoffles, L. \& Cogacz, A. (Eds). A preventive approach in inclusive education. Differentiating classroom practice for primary school teachers. In service training guide. Istanbul: Bogazici University Press. 
Lima-Rodrigues, L.M (2014) Developing the role of inclusive teachers through sociodrama Proceedings of Braga 2014 Embracing Inclusive Approaches for Children and Youth with Special Education Needs Conference, 37-40.

Karkou, V.(Ed). (2010). Arts therapies in schools: research and practice. London and Philadelphia: Jessica Kingsley Publishers.

Mayesky, M. (2009). Creative activities for young children. N.Y.: Delmar.

McFerrana, K.S., Thompsona, G. \& Bolgerb, L. (2015). The impact of fostering relationships through music within a special school classroom for students with autism spectrum disorder: an action research study. Educational Action Research, 24(2). doi.org/10.108 0/09650792.2015.1058171

Oliveira, T.A.S. (2009). Educação Inclusiva e formação de professores (Master dissertation). University of Coimbra.

Peter, M. (2009). Drama: narrative pedagogy and socially challenged children. British Journal of Special Education, 36(1), 9-17.

Peebles, J. \& Mendaglio, S. (2014). Preparing teachers for inclusive classrooms: Introducing the individual direct experience approach. Learning Landscapes, 7(2), 245-257.

Punch, K. (1998). Introduction to social research: Quantitative and qualitative approaches. London: Sage Publications.

Read, H. (1982). Educação pela arte. Lisboa: Edições 70.

Rees, M. (2005). Drawing on difference-Art therapy with people who have learning difficulties. N.Y: Routledge.

Regev, D. \& Guttmann, J. (2005). The psychological benefits of artwork: The case of children with learning disorders. The Arts in Psychotherapy, 32, 302-312

Reicher, H. (2010). Building inclusive education on social and emotional learning: Challenges and perspectives - a review. International Journal of Inclusive Education, 14 (3), 213-246.

Rodrigues, D. (2006). Dez ideias (mal) feitas sobre a educação inclusiva. In D. Rodrigues (Ed.). Educação Inclusiva - Estamos a fazer progressos? (p. 75-88). Fórum de Estudos de Educação Inclusiva. Lisboa: FMH Edições. 
Santos, A. (2008). Mediações arteducacionais. Coimbra: Fundação Calouste Gulbenkian.

Santos, G. D. (1999). A dança e o movimento criativo no desenvolvimento da competência social - uma abordagem às terapias expressivas (Master dissertation). Faculdade de Motricidade Humana, U.T.L.

Santos, G.D. (2008). Dançoterapia integrativa na transformação de relações interpessoais. International Journal of Developmental and Educational Psychology, XX, 1(3), 163-173.

Santos, G.D. \& Lima-Rodrigues, L. (2016). Expressive arts - embodying inclusive teachers. Journal of Research in Special Educational Needs, 16(1), 506-509. doi: 10.1111/14713802.12177

Santos, G. D., Ljusberg, A. \& Candeias, A. (2009). Classroom climate in inclusive settings. Proceedings of International Conference Changing Practices in Inclusive Schools, University of Évora. (ISBN: 978-989-95539-5-8)

Santos, G.D. \& Simões, M. (2009). Mediadores artístico-expressivos como promotores da interacção social na criança com perturbação do espectro do autismo. In I. Gomes, \& M. Maia (Eds.), Special education: From theory to practice. Local: University Fernando Pessoa editions. (ISBN 978-989-643-033)

Santos, G. D. \& Vaz-Velho, C. (2011). Experiential group processes in graduate training of psychologists: The case of "Expressive Therapies" and "Group Psychotherapies" at University of Évora. Proceedings of 4th Regional Mediterranean Congress of International Association of Group Psychotherapy, Porto.

Schaffner, C. B. \& Buswell, B. E. (1999). Dez elementos críticos para a criação de comunidades de ensino inclusivo e eficaz. In S. Stainback \& W. Stainback, Inclusão - um guia para educadores (pp. 69-87). Porto Alegre: Edições Artmed.

Sharma, U. (2010) Using reflective practices for the preparation of pre-service teachers for inclusive classrooms. In C. Forlin (Ed.), Teacher education for inclusion. Changing paradigms and innovative approaches. London: Routledge.

Soodak, L. (2003). Classroom management in a diverse society. Theory into Practice, 42(4), $327-$ 333. 
Suleymanov, F. (2015). Issues of inclusive education: Some aspects to be considered, Electronic Journal for Inclusive Education, 3(4).

UNESCO (2009). Policy guidelines on inclusion in education. Paris: UNESCO.

Valente, L., Lourenço, C., \& Charréu, L. (1998) Educação pela arte: uma experiência portuguesa. Actas III Jornades D’História de LÉducació Artística.Universitat de Belles Arts, Facultat de Barcelona.

Valente, L., Peixoto, A., \& Craveiro Lopes, J. (2003). Re-encantar a formação de professores através das expressões artísticas integradas. In A. Neto et al. (Eds.), Didácticas e Metodologias de Educação- Percursos e Desafios (Vol II). Évora: Departamento de Pedagogia e Educação da Universidade de Évora.

Westling Allodi, M. (2002). A two-level analysis of classroom climate in relation to social context, grup composition and organization of special support. Learning Environments Research, 5, 253-274.

Westwood, P. (2004). Commonsense methods for children with special educational needs. London and NY: Routledge Falmer.

World Conference on Arts Education (2006). Retrieved from http://www.unesco.org/new/en/culture/themes/creativity/arts-education/world-conferences/2006-lisbon/ 